一般演題（ポスター） P1-23

\title{
自己免疫疾患および血液疾患を背景とした サイトメガロウイルス胃腸炎における臨床像の検討
} ○蜷川慶太, 神田真聡, 芳野正修, 清水裕香, 深谷進司, 菊池英明

\section{(JA 北海道厚生連 帯広厚生病院)}

【背景と目的】免疫抑制状態におけるサイトメガロウイルス (CMV) 感染症は致死的な感染症の一つである。その主要臓 器病変である CMV 胃腸炎をまとめた報告は少ないため臨床 像を検討した。【方法】 2011 年 4 月から 2017 年 5 月までに 当院で病理学的にCMV 陽性の消化管病変を認め, 抗ウイル 又薬で治療した自己免疫疾患・血液疾患（炎症性腸疾患を 除く）を持つ患者を対象とした。背景因子，血液検査，病 変の形態，治療内容を後向きに検討した。治癒後再発なく 経過したものを予後良好, 病理学的診断後に再発・死亡し たものを予後不良とした。【結果】当該症例は 24 例で, 男 性 14 例，年齢中央值 69 [49-86]歳であった。1 16 例が予後 良好, 8 例が予後不良でうち 2 例が診断後 60 日以内に死亡 した。背景疾患は関節リウマチ，血管炎，その他が 8,5 , 11 例であった。初発症状は腹痛が最多で，穿孔は 1 例，無 症状は 6 例あった。病変部位は胃が 14 例, 十二指腸, 回腸, 結腸，直腸が $3,2 ， 3,2$ 例であった．内視鏡的所見では深 い潰瘍が 9 例，発赤が 17 例，辺縁のびらんが 20 例， 円形. 直線状が 11 例，白苔ありが 19 例，多発が 21 例であった。 血液検査ではリンパ球数や Alb, IgG が低值であった。治療 薬はガンシクロビルが 23 例で使用された。全治療期間は中 央值が 15 日で, 9 例で維持治療が行われた。 18 例が初期治 療後内視鏡を施行され，5例が治癒確認後再燃していた。 【結語】サイトメガロウイルス胃腸炎の臨床像に関して検討 を行った。 